\title{
GLACIER INVENTORIES OF ICELAND: EVALUATION AND USE OF SOURCES OF DATA
}

\author{
by
}

R.S. Williams Jr.

(U.S. Geological Survey, Reston, Virginia 22092, U.S.A.)

\begin{abstract}
All sources of cartographic, aerial photographic, satellite image, and related data, from the 18 th century to the present, for the eight geographic groups of Iceland's glaciers, were evaluated for use in preparing a preliminary inventory of Iceland's glaciers, based on information requirements of the Temporary Technical Secretariat for World Glacier Inventory. On the basis of an evaluation of all sources of historic and modern data for the Langjökull Group, the 1:50 000 scale U.S. Army Map Service Series C762 maps of Iceland were determined to be the best maps from which to derive information for a preliminary inventory, as long as the limitations of these maps are considered and accommodated. The fluctuations of Langjökull's principal outlet glaciers on maps and Landsat images were found to be consistent with field observations at the International Hydrological Decade monitoring stations. Accumulation area ratios were calculated from late summer snow lines on 1973 Landsat images of Vatnajökull (0.70), Langjökull (0.78), and Mýrdalsjökull (0.35). Measurements of the area of the now stagnant glacier on Ok showed a rapid reduction in area (68 per cent) between 1910 and 1960, but a decline in rate of wastage since 1960 (73 per cent between 1910 and 1978). From 1910 and 1945 topographic maps, the volume of the glacier on $\mathrm{Ok}$ was found to be reduced by $0.62 \mathrm{~km}^{3}$.
\end{abstract}

\section{INTRODUCTION}

A great variety of maps, both historic and modern, aerial photographs, satellite images, and related information are available of Iceland and these have been used by many scientists for glaciological studies, including the preparation of glacier inventories. It is the objective of this paper to evaluate the most important of these sources of data and to assess the usefulness of the 20th century cartographic and image data for the preparation of a modified Level 4 inventory of Iceland's glaciers, according to the "Guidelines for Preliminary Inventories" set forth by the Temporary Technical Secretariat for the World Glacier Inventory (TTS/WGI) (Scherler 1983). Because of the difficulty in preparing comprehensive glacier inventories of many regions, according to the initial guidelines set forth by Müller and others (1977), Scherler (1983) developed a simplified Level $1,2,3$, or 4 inventory scheme that is based on Landsat images with or without the supplementary use of maps and aerial photographs.

The latter part of the paper will apply the glaciological information that can be gleaned from various types of modern cartographic, image, and other data to one of Iceland's eight glacier groups, the Langjökull Group (Fig.1.). In this way the glaciological value of these diverse data for the preparation of a glacier inventory can be directly evaluated for a complex group of nine glaciers in the Langjökull Group, first studied in the mid-1700's (Vidalin 1754, Ólafsson $1975(1772)$ ) and first mapped in 1792 (Pálsson 1795).

\section{DISTRIBUTION OF GLACIERS}

Most of the glaciers in Iceland, both in terms of area and volume, occur as ice caps (Fig.1.). The ice caps range in area from a few square kilometers (for example, $4.0 \mathrm{~km}^{2}$ for the glacier on Ok) to several thousand square kilometers (8300 $\mathrm{km}^{2}$ for Vatnajökull).

It was found convenient, from a glacier-inventory viewpoint, to group Iceland's glaciers according to eight geographic clusters (Fig.1.): Vestfirdir, Snaefellsjökull, Langjökull, Myrdalsjökull, Hofsjökull, Tröllaskagi (Nordurlandsjöklar), Vatnajökull, and Austfirdir. Rist (written communication, 1985) has also grouped Iceland's glaciers into eight clusters, although his grouping is slightly different from Fig.1. The number of glaciers in each group ranges from one in the case of Snaefellsjökull, a solitary ice cap, to about 115 Alpine-type cirque and valley glaciers (according to Björnsson 1980b) in the Tröllaskagi Group. The names of the glaciers in the glacier groups are from the 1:100 000 scale Atlas sheets of Iceland and the published works of Thorvaldur Thoroddsen, Jón Eythórsson, Sigurdur Thorarinsson (especially Thorarinsson 1943), and volumes of the journal Jökull.

\section{HISTORICAL REVIEW OF GLACIER INVENTORIES}

Thorarinsson (1960) provides an excellent review of the published historical record on observations of Iceland's glaciers before the beginning of the 19th century, especially with reference to the pioneering work of Sveinn Pálsson, who prepared the first detailed maps of some of the glaciers of Iceland (Pálsson 1795, Eythórsson 1945, Sigurdsson 1978). The primary basis for compiling an inventory of glaciers of any area, however, is the availability of adequate maps and, until the beginning of the 20th century, when 1:50 000 scale and 1:100 000 scale map series were initiated by Danish surveyors and cartographers, the lack of a good cartographic base to plot field observations of glaciers was a serious handicap.

Thorvaldur Thoroddsen was the first scientist to study all of Iceland's glaciers systematically (Thoroddsen 1892, 1906, 1911). Thoroddsen had a significant advantage over Sveinn Pálsson in that the 1:480 000 scale color map of Iceland by Gunnlaugsson (1844) was available. Although the Norwegian, Amund Helland (1883), used this map to calculate areas of eight of Iceland's glaciers, Thoroddsen $(1892,1906)$ provided information on areas, as well as information of glaciological value (for example, highest and lowest elevation above sea level, height of the snow line, and number of outlet glaciers) about Iceland's glaciers. Thoroddsen gave the total area of glaciers in Iceland as $13530 \mathrm{~km}^{2}$ (Thoroddsen 1906), but this area can only be used in a semi-quantitative sense because of geodetic deficiencies in his base map (Thoroddsen 1901), which is a modification of the 1844 Gunnlaugsson map.

In 1930, Jón Eythórsson began a systematic program of annual measurements of the fluctuation of termini of selected glaciers in Iceland (Eythórsson, 1963). Since Eythórsson's death in 1968, the annual measurements have been supervised by Sigurjón Rist (1967b, 1977, 1983). During the International Hydrological Decade (IHD) (1965-1974), glacier termini, measured on an annual basis, were assigned the numbers shown on Figure 1. At the present time, Rist and his colleagues monitor 34 termini. Eythórsson's and Rist's work provides a continuous record of fluctuation of selected glacier termini for more than 50 years, in some cases, and provides an important bridge 


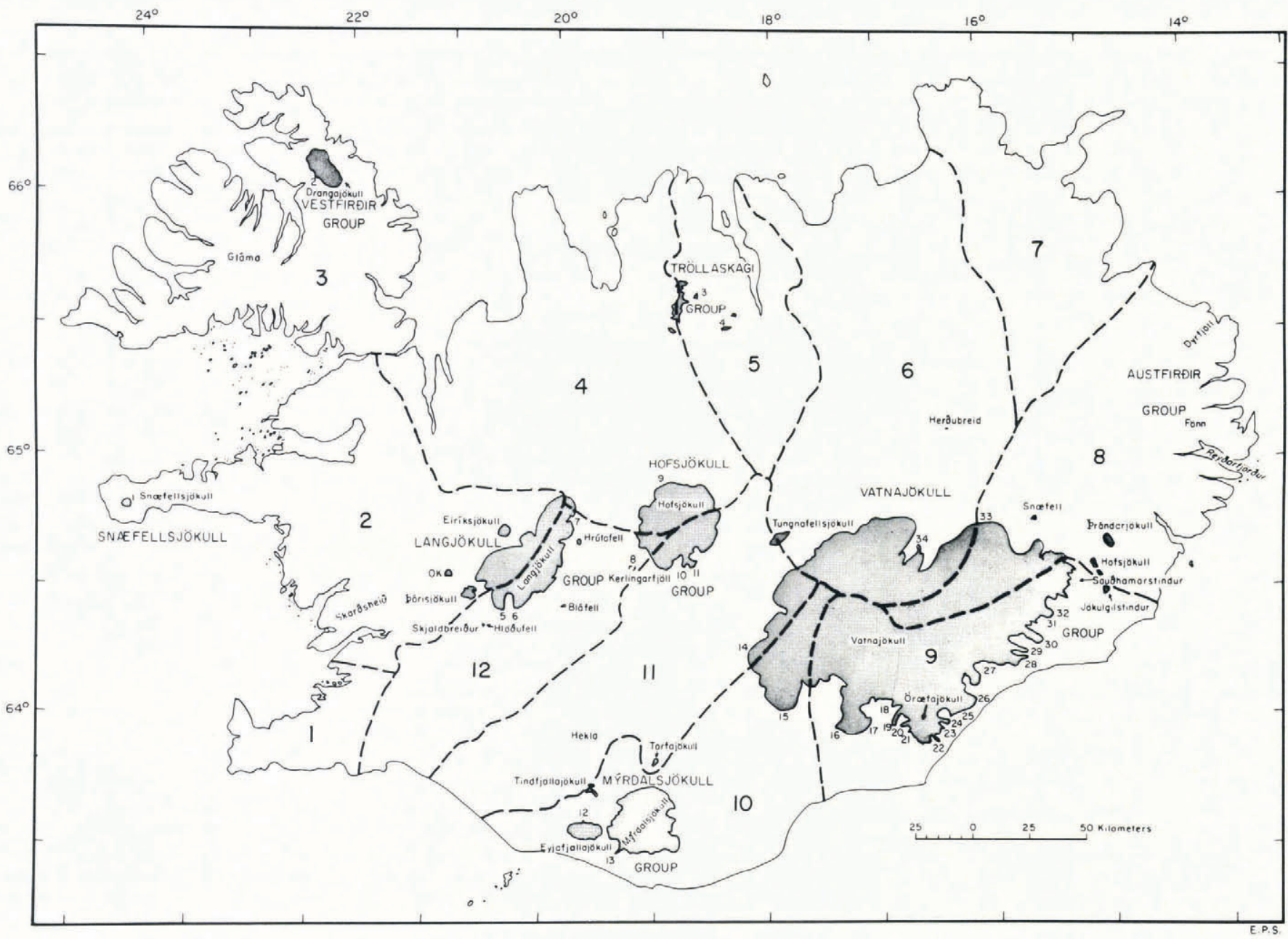

Fig.1. Index map to the 8 groups of glaciers included in an inventory of Iceland's glaciers. The drainage divides between the 12 sectors of the Hydrological Network of Iceland are shown with a dashed line (Iceland National Energy Authority, 1972). The 34 numbers associated with many of the glaciers are International Hydrological Decade (IHD) index numbers assigned by Rist (1967 and 1977) to margins of glaciers monitored annually.

TABLE I. AREA OF ICELAND COVERED BY GLACIERS (from published and unpublished sources)

\begin{tabular}{|c|c|c|c|c|}
\hline Author & Source material & $\begin{array}{c}\text { Publication } \\
\text { date }\end{array}$ & $\begin{array}{l}\text { Total glacier } \\
\text { area }\left(\mathrm{km}^{2}\right)\end{array}$ & $\begin{array}{l}\text { Per cent of } \\
\text { Iceland's } \\
\text { conterminous } \\
\text { area } \\
102950 \mathrm{~km}^{2}\end{array}$ \\
\hline Ágúst Bödvarsson & $\begin{array}{l}\text { 1:600 } 000 \text { scale map } \\
\text { by Thorvaldur } \\
\text { Thoroddsen (1901) }\end{array}$ & unpublished & 13809 & 13.4 \\
\hline Thorvaldur Thoroddsen & $\begin{array}{l}\text { Field observations } \\
\text { plotted on Björn } \\
\text { Gunnlaugsson's map } \\
\text { (1844) }\end{array}$ & 1906 & 13530 & 13.2 \\
\hline Sigurdur Thorarinsson & $\begin{array}{l}1: 500000 \text { scale and } \\
\text { 1:100 } 000 \text { scale Danish } \\
\text { Geodetic Institute Maps }\end{array}$ & 1943 & 11785 & 11.4 \\
\hline Helgi Björnsson & $\begin{array}{l}\text { Landsat images, aerial } \\
\text { photographs, and } ~ \\
20 \mathrm{~km}^{2} \text { from an un- } \\
\text { identified source }\end{array}$ & $1980 \mathrm{a}$ & 11260 & 10.9 \\
\hline
\end{tabular}


between the discontinuous record from maps, aerial photographs, and satellite images. Also during the 1930s, Eythórsson (1931, 1935), Eiriksson (1932), and Bárdarson (1934) prepared glacier-inventory information on a few glaciers in Iceland.

Thorarinsson (1943) used 1:50 000 scale and 1:100 000 scale Danish Geodetic Institute maps in compiling a comprehensive inventory of Iceland's glaciers and also published new areas of the 13 largest ice caps in Iceland, from later revisions to the 1:100 000 scale Danish maps (Thorarinsson 1958).

Björnsson (1974) discussed the information needs for a glacier inventory of Iceland on the basis of various sources of data and briefly reviewed previous inventories of Iceland. Björnsson (1980a) measured the area of ice caps on Landsat images and used aerial photographs, acquired by the U.S. Air Force in 1960, to measure the areas of Drangajökull, Snaefellsjökull, and 115 glaciers in the Tröllaskagi Group. $\mathrm{He}$ added areas of other glaciers $\left(20 \mathrm{~km}^{2}\right)$ for a total of $11260 \mathrm{~km}^{2}$. Williams (1983) summarized information about the changing areas of the 13 largest ice caps in Iceland (the same 13 as discussed by Thorarinsson (1958)).

Table I gives a summary of the total area of Iceland covered by glaciers, from various sources. Although all of these are based on the best available maps at the time, or from vertical aerial photographs and satellite images, it is clear that each source of data has deficiencies that limit its usefulness in preparing a comprehensive and accurate inventory of Iceland's glaciers. Because of serious deficiencies in maps of glaciers of Iceland prior to 1903, data from such maps can only be used in a qualitative sense.

\section{EVALUATION OF SOURCES OF DATA FOR GLACIER INVENTORIES}

\section{Maps}

Table II summarizes maps of Iceland, published in the 20th century, that provide qualitative (pre-1905) and quantitative (post-1904) information needed to compile an inventory of Iceland's glaciers. Both the 1:100 000 scale Atlas sheets (Atlasblöd) and the 1:50 000 scale Quarter sheets (Fjördungsblöd) contain glacier-inventory information but have several deficiencies. According to Nørlund (1944), the Danish General Staff started preparations for the mapping of Iceland in 1900, with the first 1:50 000 scale map of a glacier (south-eastern Vatnajökull) surveyed in 1903. By 1920, the Danish General Staff had worked clockwise around the coast to the western part of the Tröllaskagi peninsula. In 1930, the Danish Geodetic Survey started up the mapping again, reaching the south-east coast in 1936. The central part of Iceland was mapped by a combination of field surveys and oblique aerial photogrammetry from aerial photographs acquired in 1937 and 1938 (Nørlund 1938). Figure 2 shows the course of the 37-year mapping program by the Danes. The 36-year span of the surveys of the glaciers of Iceland limits the use of these maps for glacier-inventory work for two reasons: (1) country-wide, time-restrictive comparisons of glacier area are impossible because glaciers were mapped at various times during the period, which was at a time of rapid recession of Iceland's glaciers, because of the climatic warming (Thoroddsen 1916-17, Eythórsson 1949, Sigbjarnarson 1969, Central Intelligence Agency 1974, Bergthorsson 1985), and (2) Iceland's largest ice caps were mapped piecemeal (for example, Vatnajökull from 1903 to 1939, Mýrdalsjökull from 1904 to 1938). Another deficiency is in the plane-table survey method. Topographic contours and other features, such as lakes, are sketched in by the surveyor between stadia-rod positions. Geodetic monuments and summit elevations, however, are generally surveyed accurately. The determination of glacier margins from field observations or analysis of oblique aerial photographs (1937 and 1938) is necessarily subjective and depends on the experience of the surveyor, rodman and cartographer.

Those in the AMS Series C762 are the most accurate large scale maps available of the glaciers of Iceland, but several deficiencies exist for glacier-inventory work: (1) variety of compilation methods, (2) lack of ground control, and (3) time of year when surveys were made. The AMS Series C762 maps of Iceland's glaciers were compiled by photogrammetric (multiplex) methods, but each map has been compiled by one or more of the following methods: photo-stereo, photo-planimetric, Danish Atlas or Quarter sheets. The Danish maps were used where no aerial photographs were available (cloud cover) or as a base for planimetric revisions from aerial photographs, where no stereo coverage was available. Ground control for the maps was based on bench marks shown on the Danish maps and identified on the photographs. Some of the aerial

TABLE II. MAPS AND MAP SERIES USED TO COMPILE INVENTORIES OF ICELAND'S GLACIERS

\begin{tabular}{|c|c|c|c|c|c|c|c|}
\hline $\begin{array}{c}\text { Type of } \\
\text { survey }\end{array}$ & $\begin{array}{l}\text { Map scale } \\
\text { and type }\end{array}$ & Source & Remarks & $\begin{array}{l}\text { Map or map } \\
\text { series }\end{array}$ & $\begin{array}{l}\text { Number } \\
\text { of maps } \\
\text { that in- } \\
\text { clude } \\
\text { glaciers }\end{array}$ & $\begin{array}{l}\text { Publica- } \\
\text { tion } \\
\text { date(s) }\end{array}$ & $\begin{array}{l}\text { Survey date(s) } \\
\text { of } \\
\text { glaciers }\end{array}$ \\
\hline Field & $1: 600000$ & Thoroddsen (1901) & Color map & $\begin{array}{l}\text { Geological Map } \\
\text { of Iceland }\end{array}$ & 2 sheets & 1901 & $1880-1898$ \\
\hline Plane-table & $\begin{array}{l}\text { 1:50 } 000 \\
\text { topographic }\end{array}$ & $\begin{array}{l}\text { Danish Geodetic } \\
\text { Institute (Dansk } \\
\text { Geodaetisk Institut) }\end{array}$ & $\begin{array}{l}\text { Coverage of Iceland incomplete. } \\
\text { Only } 118 \text { sheets completed of the } \\
\text { southeast, south, southwest, west, } \\
\text { and northwest coasts by the Danish } \\
\text { General Staff (1900-1920) and the } \\
\text { Danish Geodetic Survey } \\
(1930-1944)\end{array}$ & $\begin{array}{l}\text { Quarter sheets } \\
\text { (Fjordungsblod) }\end{array}$ & 22 & $\begin{array}{l}1905-1915 \\
\text { (a few sheets } \\
\text { revised in } \\
1950-1954)\end{array}$ & $1903-1914$ \\
\hline $\begin{array}{l}\text { Plane-table } \\
\text { and oblique } \\
\text { aerial photo- } \\
\text { graphs }\end{array}$ & $\begin{array}{l}\text { 1:100 } 000 \\
\text { topographic }\end{array}$ & $\begin{array}{l}\text { Danish Geodetic } \\
\text { Institute (Dansk } \\
\text { Geodaetisk), Iceland } \\
\text { Geodetic Survey) } \\
\text { (Landmaelinger } \\
\text { islands), Nørlund } \\
\text { (1944) }\end{array}$ & $\begin{array}{l}\text { Coverage of Iceland complete with } \\
87 \text { sheets by the Danish General } \\
\text { Staff (1900-1920) and the Danish } \\
\text { Geodetic Survey (1930-1944). } \\
\text { Later revised editions by Iceland } \\
\text { Geodetic Survey (1944 to present) } \\
\text { (See Fig.2.) }\end{array}$ & $\begin{array}{l}\text { Atlas sheets } \\
\text { (Atlasblod) }\end{array}$ & 32 & $\begin{array}{l}1932-1944 \\
\text { (a few sheets } \\
\text { revised in } \\
\text { post-1944 } \\
\text { period) }\end{array}$ & $\begin{array}{l}\text { 1903-1939 } \\
\text { including } \\
\text { oblique aerial } \\
\text { photo surveys } \\
\text { in } 1937-38 \\
\text { (Nørlund 1938) }\end{array}$ \\
\hline $\begin{array}{l}\text { Photogrammetry. } \\
\text { Vertical aerial } \\
\text { photos. Control } \\
\text { by Danish } \\
\text { Quarter and } \\
\text { Atlas maps }\end{array}$ & $\begin{array}{l}\text { 1:50 } 000 \\
\text { topographic }\end{array}$ & $\begin{array}{l}\text { U.S. Army Map } \\
\text { Service, now U.S. } \\
\text { Defense Mapping } \\
\text { Agency }\end{array}$ & $\begin{array}{l}\text { Coverage of Iceland complete with } \\
297 \text { sheets. New 1:50 000 scale map } \\
\text { series (Series C761) begun by the } \\
\text { Defense Mapping Agency and } \\
\text { Iceland Geodetic Survey. Only } \\
\text { southwest Iceland covered by } 11 \\
\text { new maps. }\end{array}$ & $\begin{array}{l}\text { AMS Series } \\
\text { C762 }\end{array}$ & 75 & $\begin{array}{l}1950 \text { and } \\
1951\end{array}$ & $\begin{array}{l}\text { Sept/Oct } 1945 \\
\text { Aug/Sept/Oct } \\
1946 \text { aerial } \\
\text { photographs }\end{array}$ \\
\hline
\end{tabular}



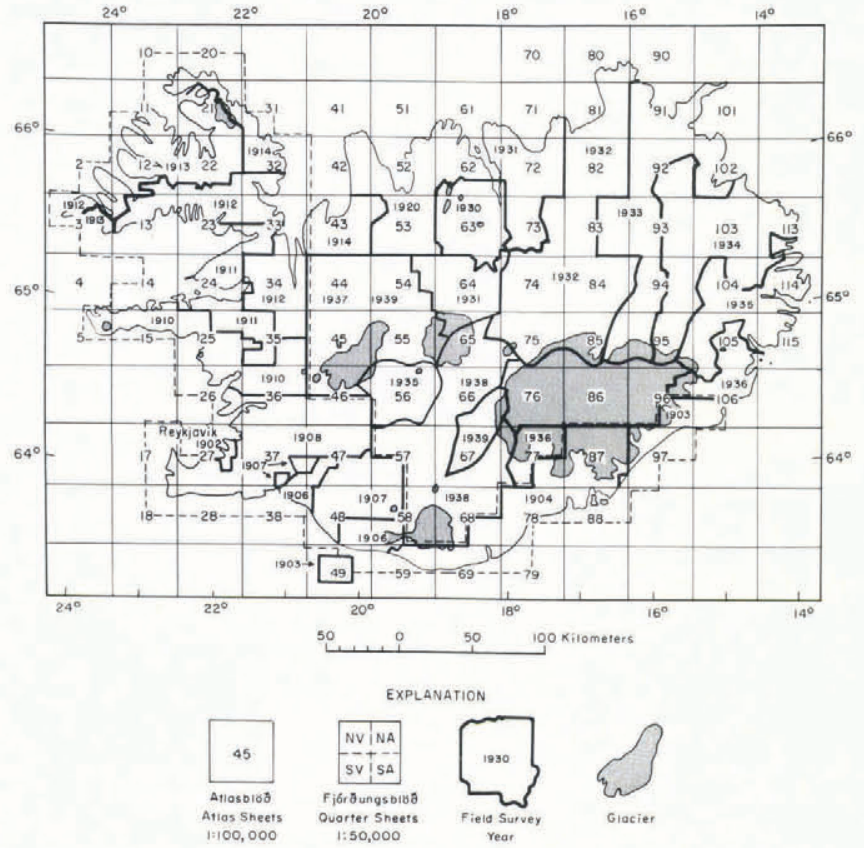

Fig.2. Index map to the 87 1:100 000 scale Atlas Sheets (Atlasblöd) (light solid lines) and $118 \quad 1: 50000$ scale Quarter Sheets (Fjórdungsblöd) (dashed lines) of Iceland, mapped between 1902 and 1939 by the Danish General Staff (1900-1920), the Danish Geodetic Institute (1930-1944), and the Iceland Geodetic Survey (1944 to present) and the years in which field surveys were carried out (heavy solid lines). Modified from Nørlund (1944).

photographs were acquired in late September or October, when new snow cover masked the glaciers and surrounding terrain.

The AMS Series C762 maps have considerably more topographic and geomorphic information than the Danish maps. This is important in properly positioning the 1945-1946 and more recent aerial photographs to obtain additional glaciological information and to make measurements of marginal fluctuations. The AMS Series C762 maps also show the transient snow line on the glaciers. The greatest value of aerial photographs is in their precise historical record of a glacier on a specific date.

\section{Aerial Photographs}

The most valuable sets of vertical aerial photographs of Iceland's glaciers are the two flown by the United States military in support of the two 1:50 000 scale topographic map series of Iceland. The 1945 and 1946 aerial surveys by the U.S. Army Air Force provide nearly complete coverage of Iceland, except where cloudy weather prevented aerial photography. These photographs are the basis for the 1:50 000 scale AMS Series C762 maps of Iceland. The 1956 (no glaciers surveyed) and 1959-61 aerial photographic surveys by the U.S. Air Force also provide good coverage of the glaciers of Iceland, except for parts of Vatnajökull (persistent cloud cover). These photographs were to be the basis for a new 1:50 000 scale set of maps of Iceland (AMS Series C761), but only 11 maps of southwestern Iceland, in cooperation with the Iceland Geodetic Survey, have been completed. All other sets of aerial photographs, German (early 1930s (Iwan 1935) and 1942 (Bragason 1985)), Danish (1937 and 1938 (Nørlund 1938, 1944)), Icelandic (1954 to the present (Iceland National Research Council 1976; Thorvaldur Bragason, written communication, 1985)), U.S. Air Force Cambridge Research Laboratories (1968). U.S. Navy (1973), and National Aeronautics and Space Administration (1968 and 1973)), provide only limited coverage of Iceland's glaciers.

\section{Satellite Images}

A complete set of optimum Landsat 1, 2, and 3 multispectral scanner (MSS) and Landsat 3 return beam vidicon (RBV) images of Iceland is available for glaciological studies. The optimum images have been gleaned from hundreds of Landsat images of Iceland, the best of which have been catalogued by Gudbergsson and Williams (unpublished). The advantages of Landsat images lie in the large area coverage, important in several ways for glaciological studies (Krimmel and Meier 1975). Some of the advantages for glacier inventories of Iceland are as follows: (1) entire glaciers or groups of glaciers of Iceland can be imaged in a single scene, (2) fluctuations in margins of glaciers can be measured, (3) areas of glaciers can be determined, (4) transient snow line positions can be delineated, and (5) each image provides a historical record on a precise date (Williams, 1979, 1983, Williams and Thorarinsson 1974, Williams and others 1974, 1975, 1979). The main disadvantages in using satellite images for glacier inventories are (1) time of acquisition not optimum to record minimum snow cover (end of ablation season), (2) too much cloud cover, and (3) difficulty in determining the actual margin of the debris-covered glacier termini.

The delineation of the late summer snow line on Landsat images of Icelandic ice caps has important glaciological value, particularly if images permit mass-balance characteristics to be inferred (Østrem 1975). The accumulation area ratio (AAR) for Vatnajökull on the 22 September 1973 image was 0.7, while the AAR for Mýrdalsjökull on the same image was only 0.35 . This may suggest that Vatnajökull was in equilibrium during 1972-73, but that Mýrdalsjökull had a negative mass balance during the same period. (c.f. Glen, 1963).

\section{Related Data}

Very few mass-balance studies have been conducted of Icelandic glaciers. Those that have been accomplished have only a short time series, such as the 1936-38 studies of Hoffellsjökull, an outlet glacier of Vatnajökull in southeast Iceland (Ahlmann 1939, Thorarinsson 1939) and the 1967-68 studies by Björnsson (1972) of the cirque glacier, Baegisárjökull, in the Tröllaskagi Group.

During the 1950s, seismic surveys were used to determine the thickness of parts of Vatnajökull (Eythórsson 1951, 1952) and Mýrdalsjökull (Rist 1967a). In 1975,

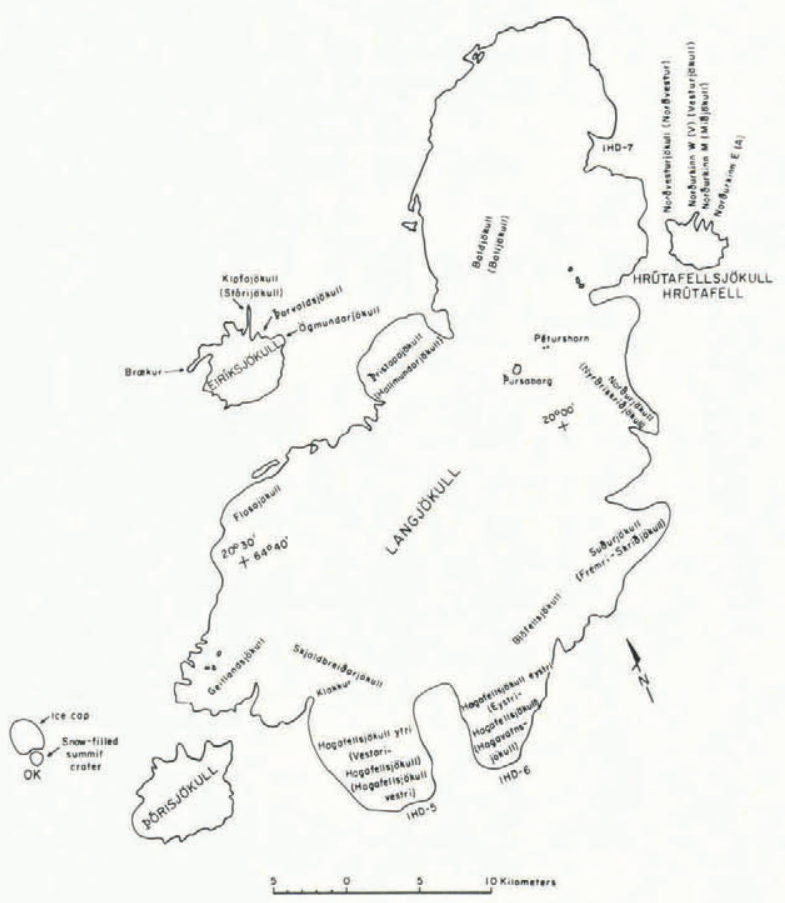

Fig.3. Index map to the 5 principal glaciers (ice caps) in the Langjökull Group. Historic and modern geographic place-names of the glaciers, margins of Langjökull, and other features, such as nunataks (Thúrsaborg), have been culled from various published Icelandic sources. Outlines of glaciers from Landsat MSS image (22045-12131) of 28 August 1980 
TABLE III. LANGJÖKULL GROUP. AREA IN SQUARE KILOMETERS OF THE NINE GLACIERS IN THE GROUP FROM HISTORIC AND MODERN MAPS OF ICELAND

\begin{tabular}{|c|c|c|c|c|c|c|c|}
\hline Glacier name & $\begin{array}{l}\text { Geological map } \\
\text { of Iceland } \\
\text { Thoroddsen } \\
(1901)\end{array}$ & $\begin{array}{c}\text { Thorvaldur } \\
\text { Thoroddsen } \\
\text { (1906) }\end{array}$ & $\begin{array}{l}\text { Sigurdur } \\
\text { Thorarinsson } \\
\text { (1943) }\end{array}$ & $\begin{array}{l}\text { Dates of surveys } \\
\text { of Danish } \\
\text { Atlas/Quarter } \\
\text { sheets used by } \\
\text { Thorarinsson } 1943\end{array}$ & $\begin{array}{l}\text { AMS Series } \\
\text { C762 Maps }\end{array}$ & $\begin{array}{l}\text { Dates of vertical } \\
\text { aerial photographs } \\
\text { used for AMS Series } \\
\text { C762 and use of } \\
\text { Danish maps }\end{array}$ & $\begin{array}{c}\text { Landsat } \\
\text { MSS Image } \\
22045-121310 \\
28 \text { Aug } 1980\end{array}$ \\
\hline Langjőkull & $\begin{array}{c}1271 \\
\text { (includes } \\
\text { Thórisjokull) }\end{array}$ & $\begin{array}{l}1300 \\
\text { (includes } \\
\text { Thórisjkokull) }\end{array}$ & 1021 & $\begin{array}{c}1935 \\
1937-1938\end{array}$ & 985.0 & $\begin{array}{l}\text { Sept/Oct } 1945 \\
\text { Aug/Sept and Oct } 1946 \\
\text { and Danish maps }\end{array}$ & $954.4 \pm 1.6$ \\
\hline Thórisjőkull & & & 34.5 & 1938 & 34.0 & Aug 1946, Sept/Oct 1945 & $31.9 \pm 0.6$ \\
\hline Glacier on Ok & 50 & 35 & 15.0 & 1910 & 6.8 & 23 Sept 1945 & $3.8 \pm 0.6$ \\
\hline Eiriksjokull & 90 & 100 & 23.5 & 1938 & 22.0 & Oct 1945 and Danish maps & $23.8 \pm 0.6$ \\
\hline $\begin{array}{l}\text { Glacier on } \\
\text { Hrútafell } \\
\text { (Hrútafells- } \\
\text { jokull) }\end{array}$ & 22 & - & 11.2 & 1938 & 7.5 & Oct 1946 & $8.8 \pm 0.6$ \\
\hline $\begin{array}{l}\text { Glacier on } \\
\text { Blafell }\end{array}$ & $\begin{array}{l}\text { No glacier } \\
\text { indicated }\end{array}$ & - & 2.0 & 1938 & $\begin{array}{l}\text { no glacier } \\
\text { mapped }\end{array}$ & Aug/Sept 1945 & $\begin{array}{l}\text { If present, too } \\
\text { small for MSS }\end{array}$ \\
\hline $\begin{array}{l}\text { Glacier on } \\
\text { Hlødufell }\end{array}$ & 14 & 10 & 1.2 & 1908 & $\begin{array}{l}\text { no slacier } \\
\text { mapped }\end{array}$ & Sept 1945 & $\begin{array}{l}\text { If present, too } \\
\text { small for MSS }\end{array}$ \\
\hline $\begin{array}{l}\text { Glacier on } \\
\text { Skjaldbreidur }\end{array}$ & 14 & 5 & 0.0 & 1908 & $\begin{array}{l}\text { no glacier } \\
\text { mapped }\end{array}$ & Sept 1945 & No glacier present \\
\hline $\begin{array}{l}\text { Glacier on } \\
\text { Skardsheidi }\end{array}$ & $\begin{array}{l}\text { No glacier } \\
\text { indicated }\end{array}$ & - & 0.2 & 1910 & 0.0 & Sept 1945(?) & $\begin{array}{l}\text { If present, too } \\
\text { small for MSS }\end{array}$ \\
\hline
\end{tabular}

Björnsson (1977) initiated a ground-based series of radio echo-sounding surveys of the major ice caps of Iceland. Parts of Mýrdalsjökull and Vatnajökull have been completed (Björnsson 1978), as well as Hofsjökull (Helgi Björnsson, personal communication).

Changes in volume of Iceland's glaciers can be calculated directly from measurement of changes in thickness, or

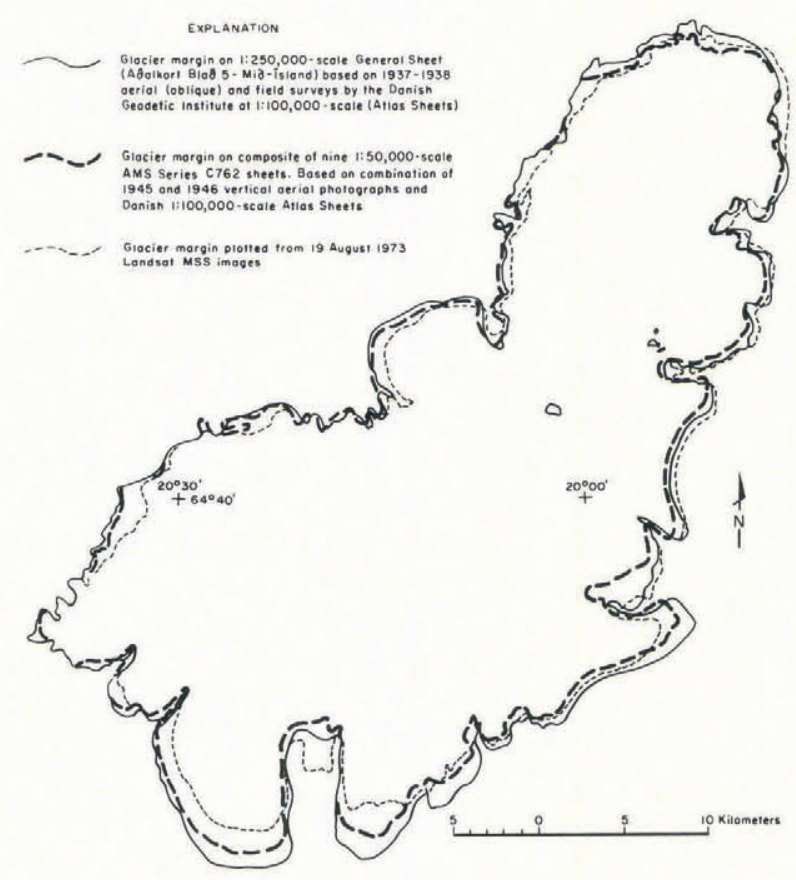

Fig.4. Outline of Langjökull, the principal glacier in the Langjökull Group, from two map series and a 19 August 1973 Landsat MSS image, indicating that the fluctuation in the margin of the ice cap has been mainly in the recession of the outlet glaciers, Thristapajökull, Sudurjökull, Hagafellsjökull eystri and Hagafellsjökull ytri (see Fig.3.). inferred from discrepancies in measurements of precipitation and runoff (Sigbjarnarson 1967, 1971). Changes in thickness can be determined by radio echo-sounding, conventional ground traverses (Freysteinsson 1984), or aerial photogrammetry.

\section{USE OF DATA SOURCES FOR GLACIER INVENTORIES}

\section{Langjökull Group}

The Langjökull Group is a group of nine glaciers situated in the west-central part of Iceland (Fig.1.). The following discussion of the various types of cartographic, image, and other data used to describe this group, will illuminate some of the problems associated with compiling a glacier inventory of Iceland and in merging information from different sets of data. Figure 3 shows the geographic names of 5 of the glaciers in the group that have been used on Icelandic maps and literature (for example, Thoroddsen 1911, Matthiasson 1980). The outlines of the five glaciers are drawn from the 28 August 1980 image. Table III provides a review of the mapping of the eight glaciers in the Langjökull Group, from the Danish Atlas/Quarter sheets to the 28 August 1980 Landsat image of the region.

\section{Langjökull}

Figure 4 is an overlay of maps of Langjökull from three different sources: Danish maps, AMS maps, and 19 August 1973 Landsat MSS image. The greatest changes between the glacier margins are in the recession of the Thristapajökull, Sudurjökull, Hagafellsjökull eystri, and Hagafellsjökull ytri outlet glaciers. The positions of the termini of the last two outlet glaciers in the mid-1930s, mid-1940s, and 1973 are consistent with field reports of fluctuations (Sigbjarnarson 1967, Rist 1974). Figure 5 is an overlay of two maps of Langjökull based on two Landsat images, 19 August 1973 and 28 August 1980, showing the advance of Hagafellsjökull ytri resulting from its 1980 surge (Theódórsson 1981) and the major advance of Hagafellsjökull eystri, resulting from two surges, one in 1975 (Sigbjarnarson 1977) and the other in 1980. The map positions of the termini on the Landsat images are consistent $( \pm 100 \mathrm{~m})$ with the $600 \mathrm{~m}$ surge of Hagafellsjökull 
TABLE IV. AREA OF GLACIER ON OK FROM HISTORIC AND MODERN SOURCES

\begin{tabular}{|c|c|c|c|c|}
\hline Area $\left(\mathrm{km}^{2}\right)$ & Date of sur & Irvey & Type of survey & Source \\
\hline 35 & 1792 & & Field & Pálsson (1795) \\
\hline 58 & $1831-184$ & & Field & Gunnlaugsson (1844) \\
\hline 35 & $1881-189$ & & Field & Thoroddsen $(1892,1906)$ \\
\hline 15.0 & 1910 & & Plane-table & $\begin{array}{l}\text { From Thorarinsson (1943) } \\
\text { based on Danish General Staff } \\
\text { Quarter sheets }\end{array}$ \\
\hline 6.8 & $23 \mathrm{Sep}$ & 1945 & Stereophotogrammetry & AMS Map Sheet \\
\hline 4.8 & 8 Aug & 1960 & Stereophotogrammetry & U.S. Air Force aerial photographs \\
\hline 4.0 & 5 Sep & 1978 & Stereophotogrammetry & $\begin{array}{l}\text { Iceland Geodetic Survey aerial } \\
\text { photographs }\end{array}$ \\
\hline $3.8 \pm 0.6 \mathrm{~km}^{2}$ & 28 Aug & 1980 & Photogrammetry & Landsat image \\
\hline
\end{tabular}

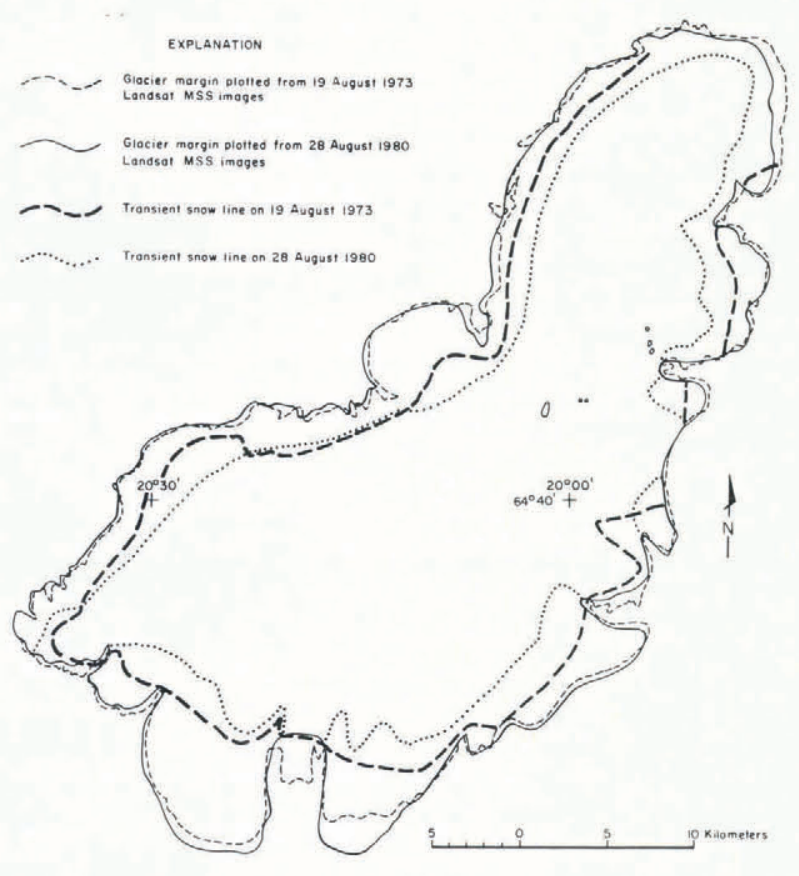

Fig.5. Outline of Langjökull, from two Landsat MSS images: 19 August 1973 and 28 August 1980. Note especially the $2.2 \mathrm{~km}$ advance of the terminus of Hagafellsjökull eystri and the lesser (about $0.5 \mathrm{~km}$ ) advance of Hagafellsjökull ytri, during this period (see Fig.3.). The transient snow lines of 19 August 1973 and 28 August 1980 are also indicated, yielding an Accumulation Area Ratio (AAR) of 0.70 and 0.65 , respectively,

ytri and the combined $2200 \mathrm{~m}$ surge of Hagafellsjökull eystri into lake Hagavatn, from which it had retreated about $2600 \mathrm{~m}$ between the late 1930s and late 1973 .

Figure 5 also shows the transient snow lines on the 19 August and 28 August 1980 Landsat images. Although not quite at the end of the summer melt period, the accumulation area ratio (AAR) was calculated to be 0.78 for the 1973 image and 0.65 for the 1980 image.

\section{Ok}

Figure 6 shows the margins of the glacier on Ok, during four stages in its recession to about $4 \mathrm{~km}^{2}$ in 1978 from $15 \mathrm{~km}^{2}$ in 1910. Figure 7 is a graph of the declining

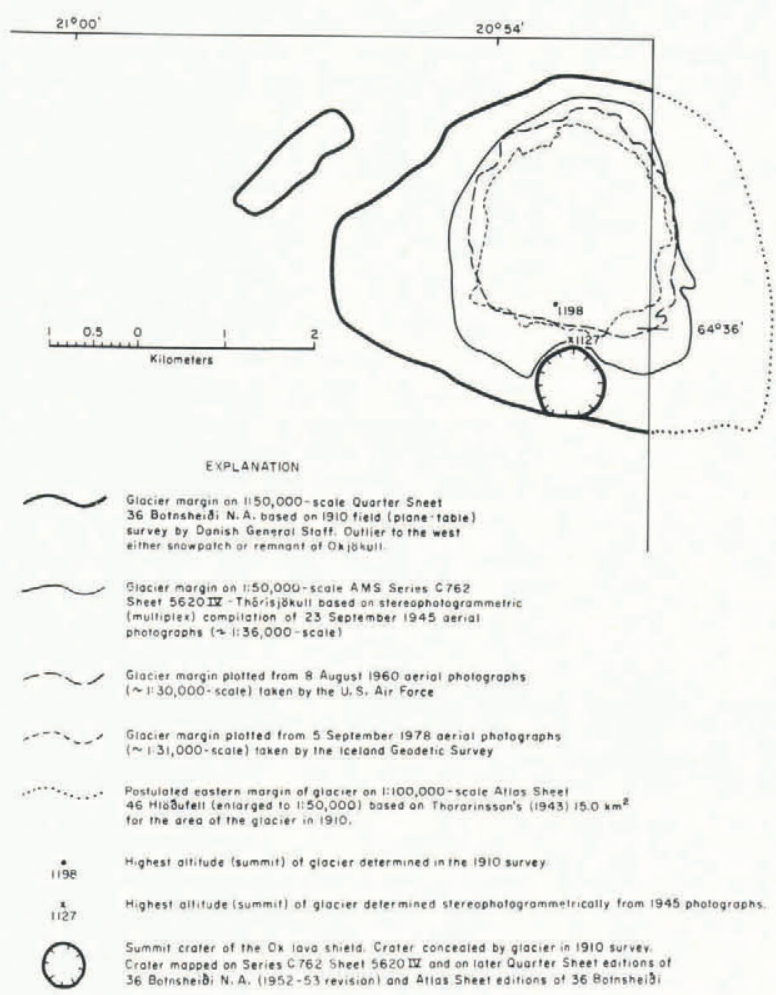

Fig.6. Outlines of the glacier on the lava shield, Ok, from two map series and two vertical aerial photographs, for a 68-year period (1910 to 1978) of recession (see Table IV) From 1910 to 1945 , the ice cap was reduced in area by $8.2 \mathrm{~km}^{2}$ or to $55 \%$ of its 1910 area. The loss in volume of ice, during this 35-year period, is estimated at $0.6 \mathrm{~km}^{3}$, from comparison of the two topographic maps.

area of the glacier on Ok, showing a rapid decline in area until about 1960 and a diminishing decline since that time. The 28 August 1980 Landsat image of the glacier shows approximately the same size as depicted on the 5 September 1978 aerial photograph. If the wastage of the glacier on Ok had continued at the same rate as between 1910 and 1950 , it would have completely disappeared by about 1980 .

The glacier on $\mathrm{Ok}$ is one of only 5 glaciers in Iceland, for which the 1:50 000 scale Quarter sheet plane-table topographic maps can be compared with 1:50 000 scale AMS Series C762 aerial photogrammetric topographic maps, to 


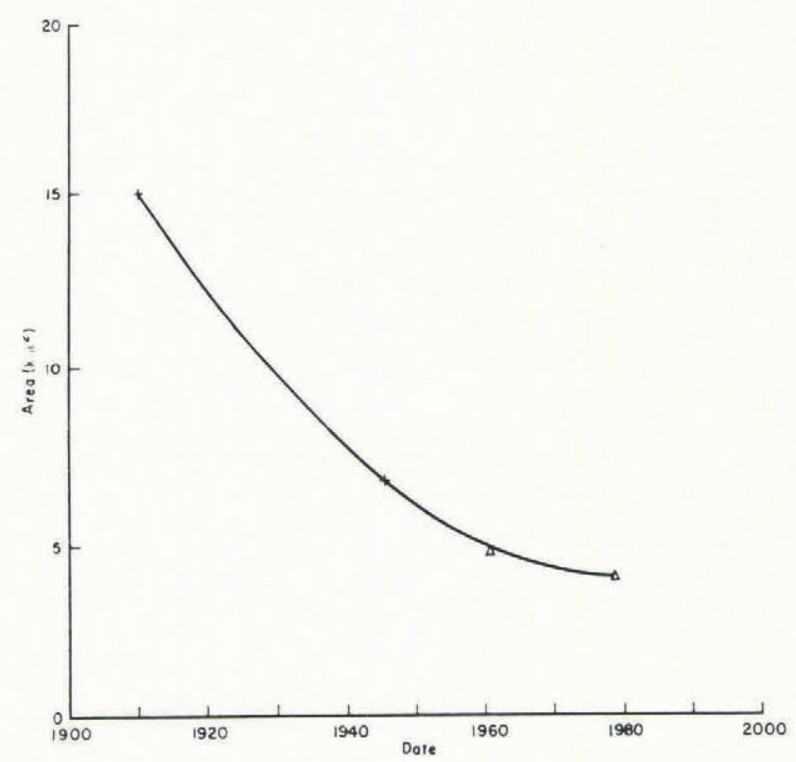

Fig.7. Graph, showing the decrease in area of the glacier on Ok between 1910 and 1978. The recession was most rapid between 1910 and about 1960, after which it slowed appreciably; otherwise, the glacier would have disappeared by about 1980. The earlier two values of area are from maps (crosses), the latter from aerial photographs (triangles).

show reduction in volume during a 30 - to 40-year interval. The others are Eyjafjallajökull, Tindfjallajökull, Snaefellsjökull, and Drangajökull. The 1910 Quarter sheet, 36 Botnsheidi N.A., shows the maximum elevation on the ice cap of $1198 \mathrm{~m}$, with the summit crater of the lava shield Ok not visible. The 1945 AMS Series C762 map, Thórisjökull, shows a maximum elevation on the ice cap of $1127 \mathrm{~m}$ or a reduction of $71 \mathrm{~m}$. When the elevation differences are computed for the two maps, for that part of the ice cap shown on the 36 Botnsheidi N.A. map (72.2 per cent of the glacier mapped in 1910), the glacier was found to be reduced by $0.45 \mathrm{~km}^{3}$ in volume. Assuming a reasonable symmetry to the ice cap, the loss from the full $15 \mathrm{~km}^{2}$ in 1910 to the $6.8 \mathrm{~km}^{2}$ in 1945 is $0.62 \mathrm{~km}^{3}$.

\section{REFERENCES}

Ahlmann W W:son 1939 Vatnajökull; scientific results of the Swedish-Icelandic investigations 1936-37-38. The regime of Hoffellsjökull. Geografiska Annaler 21(3-4): 171-188

Bärdarson G G 1934 Islands Gletscher. Visindafélag Íslendinga 16

Bergthorsson P 1985 Sensitivity of Icelandic agriculture to climatic variations. Climatic Change 7(1): 111-127

Björnsson H 1972 Bægisárjökull, North-Iceland. Results of glaciological investigations 1967-1968. Part I. Mass balance and general meteorology. Jökull 21, 1971: 1-23

Björnsson H 1974 İslenzk jöklaskrá. Jökull 23, 1973: 52

Björnsson H 1977 Thykkt jökla mæld med rafsegulbylgjum. Jökull 26, 1976: 93

Björnsson H 1978 Könnun á jöklum med rafsegulbylgjum. Náttürufradingurinn 47(3-4): 184-194

Björnsson H 1980[a] Glaciers in Iceland. Jökull 29, 1979: 74-80

Björnsson $\mathrm{H}$ 1980[b] The surface area of glaciers in Iceland. Jökull 28: 31

Bragason Th 1985 Loftmyndaflug og loftmyndir thýska flughersins af Íslandi. Mai-Október 1942. Myndaflokkar GX 12501-GX 12519. Reykjavík, Landmælingar Íslands. Loftmyndir af Îslandi (Áfangaskýrsla 1)

Central Intelligence Agency 1974 Potential implications of trends in world population, food production, and climate. Washington, DC, Office of Political Research (Report OPR-401)
Eiriksson H H 1932 Observations and measurements of some glaciers in Austur-Skaftafellssýsla. Visindafélag Íslendinga 12

Eythórsson J 1931 On the present position of the glaciers in Iceland; some preliminary studies and investigations in the summer 1930. Visindafélag Íslendinga 10

Eythórsson J 1935 On the variations of glaciers in Iceland; some studies made in 1931. Geografiska Annaler 17(1-2): $121-137$

Eythórsson J 1945 Jöklaritid. In Eythórsson J (ed) Ferdabók Sveins Pálssonar. Reykjavik, Prentsmidjan Oddi: 423-552

Eythórsson J 1949 Temperature variations in Iceland. Geografiska Annaler 31(1-4): 36-55

Eythórsson J 1951 Thykkt Vatnajökuls. Jökull 1: 1-6

Eythórsson J 1952 Landid undir Vatnajökli. Jökull 2: 1-3

Eythórsson J 1963 Variations of Icelandic glaciers 1931-1960. Jökull 13: 31-33

Freysteinsson S 1984 Tungnaárjökull - langskurdarmælingar 1959-1979. Jökull 34: 131-139

Glen J W 1963 Discussion of N N Pal'gov's paper: The relation between glacier retreat and the position of the firn line with special reference to the Zentralny Tuyuksu glacier. Bulletin of the International Association of Scientific Hydrology 8(2): 68

Gudbergsson G M, Williams R S Jr Unpublished Landsatmyndir af İslandi; MSS og RBV myndir frá Landsat 1, 2, og 3. Reykjavík, University of Iceland

Gunnlaugsson B 1844 [1848] Uppdráttr Islands, gjördr ad fyrirsögn Ólafs Nikolas Ólsens eptir landmalingum Bjarna Gunnlaugssonar, er stydjast vid Thrihyrningamal og strandamalingar thaer, sem hid konünliga Rentukammer hefir látid gjöra og reiknad hefur Hans Jakob Scheel. $1: 480,000$. Reykjavik og Kaupmannahöfn, Íslenska Bókmentafélagi

Helland A 1883 Størrelsen af Islands Jøkler. Geografisk Tidskrift $7(1): 28$

Iceland National Research Council 1976 Skipulag fjarkönnunar á Íslandi. Reykjavik, Rannsóknarád Rikisins

Iwan W 1935 Island. Studien zu einer Landeskunde. Stuttgart, Kommissionsverlag von $J$ Englehorns Nachf. (Berliner Geographische Arbeiten 7)

Krimmel R M, Meier M F 1975 Glacier applications of ERTS images. Journal of Glaciology 15(73): 391-402

Matthiasson H 1980 Langjökulsleidir. Ferdafélag Íslands. Arbók 1980

Müller F, Caflisch T, Müller G 1977 Instructions for compilation and assemblage of data for a world glacier inventory. Zürich, Swiss Federal Institute of Technology. Temporary Technical Secretariat for World Glacier Inventory

Norlund N E 1938 Denmark. Photogrammetric Engineering 4(3): 119-120

Nørlund N E 1944 Islands Kortlægning. En historisk Fremstilling. Geodatisk Instituts Publikationer 7

Ólafsson E 1975 Ferdabók Eggerts Ólafssonar og Bjarna Pálssonar um ferdir theirra á Íslandi árin 1752-1757. Vol 1. Reykjavik, Bókaútgáfan Örn og Örlygur

Østrem G 1975 ERTS data in glaciology - an effort to monitor glacier mass balance from satellite imagery. Journal of Glaciology 15(73): 403-415

Pálsson S Unpublished Forsög til en physisk, geographisk og historisk Beskrivelse over de islandske Isbjorge i Anledning af en Reise til de fornemste deraf i Aarene 1792-1794 med 4 Situations-og Prospect-Tegninger. "Om isbjerge 1792-1794." Reykjavik, Landsbókasafn İslands JS 26 Fol

Rist S 1967[a] Jöklabreytingar 1964/65, 1965/66 og 1966/67. Jökull 17: $321-325$

Rist S 1967[b] The thickness of the ice cover of Myrdalsjökull, southern Iceland. Jökull 17: 237-242

Rist S 1974 Jöklabreytingar 1931/64, 1964/73, og 1973/74. Jökull 24: 77-82

Rist S 1977 Jöklabreytingar 1964/65-1973/74 (10 ár), 1974/75 og 1975/76. Jökull 26, 1976: 69-74

Rist S 1983 Jöklabreytingar 1964/65-1973/74 (10 ár), 1974/75-1980/81 (7 ár) og 1981/82. Jökull 33: 141-145

Scherler K E 1983 Guidelines for preliminary glacier inventories. Zürich, Swiss Federal Institute of Technology. Temporary Technical Secretariat for the World Glacier Inventory 
Sigbjarnarson G 1967 The changing level of Hagavatn and glacial recession in this century. Jökull 17: 263-279

Sigbjarnarson G 1969 Næmleiki jökla fyrir vedurfarsbreytingum. In Einarsson M A (ed) Hafisinn. Reykjavik, Almenna Bókafélagid: 346-363

Sigbjarnarson G 1971 On the recession of Vatnajökull. Jökull 20, 1970: 50-61

Sigbjarnarson G 1977 Hagafellsjökull eystri hlaupinn. Jökull 26, 1976: $94-96$

Sigurdsson H 1978 Kortasaga Íslands frá lokum 16. aldar til 1848. Reykjavik, Bókaútgáfa Menningasjóds og Thjódvinafélagsins

Theódórsson Th 1981 Hagafellsjöklar taka á rás. Jökull 30, 1980: 75-77

Thorarinsson S 1939 Vatnajökull; scientific results of the Swedish-Icelandic investigations 1936-37-38. Hoffellsjökull, its movements and drainage. Geografiska Annaler 21(3-4): 189-215

Thorarinsson S 1943 Vatnajökull; scientific results of the Swedish-Icelandic investigations 1936-37-38. Oscillations of the Iceland glaciers in the last 250 years. Geografiska Annaler 25(1-2): 1-54

Th[orarinsson] S 1958 Flatarmál nokkurra islenzkra jökla samkvæmt herforingjarádskortunum. Jökull 8: 25

Thorarinsson S 1960 Glaciological knowledge in Iceland before 1800. A historical outline. Jökull 10: 1-18

Thorarinsson S, Sæmundsson K, Williams R S Jr 1974 ERTS-1 image of Vatnajökull: analysis of glaciological, structural, and volcanic features. Jökull 23, 1973: 7-17

Thoroddsen Th 1892 Islands Jøkler i Fortid og Nutid. Geografisk Tidskrift 11(5-6), 1891-1892: 111-146

Thoroddsen Th 1901 Geological map of Iceland. Surveyed in the years 1881-1898. 1:600,000 (2 sheets) [Copenhagen], The Carlsberg Fund

Thoroddsen Th 1906 Island. Grundriss der Geographie und Geologie. Die Gletscher Islands. Petermanns Mitteilungen Ergänzungbd 32(153): 163-208

Thoroddsen Th 1911 Lysing Islands. $\quad$ Bd 2. Kaupmannahöf n, Hinu İslenzka Bókmentafélagi

Thoroddsen Th 1916-17 Árferdi $\dot{a}$ Íslandi $i$ thúsund ár. Kaupmannahöfn, Hid Íslenska Frædafjelag

Vidalin Th 1754 Abhandlung von den isländischen Eisbergen. Hamburgisches Magazin 2: 9-27; 5: 197-218

Williams R S Jr 1979 Iceland - satellite monitoring of changes of glaciers of Iceland. Glaciological Data Report GD-4 Pt 1: 72-77

Williams R S Jr 1983 Satellite glaciology of Iceland. Jökull 33: $3-12$

Williams R S Jr, Thorarinsson S 1974 ERTS-1 image of the Vatnajökull area: general comments. Jökull 23, 1973: 1-6

Williams R S Jr and 8 others 1974 Environmental studies of Iceland with ERTS-1 imagery. Proceedings of the Ninth International Symposium on Remote Sensing of Environment...1974...Vol 1. Ann Arbor, Environmental Research Institute of Michigan: 31-81

Williams R S Jr, Bödvarsson Á, Rist S, Sæmundsson K, Thorarinsson S 1975 Glaciological studies in Iceland with ERTS-1 imagery. Journal of Glaciology 15(73): 465-466

Williams R S Jr, Thorarinsson S, Björnsson H, Gudmundsson B 1979 Dynamics of Icelandic ice caps and outlet glaciers. Journal of Glaciology 24(90): 505-507 